\title{
VULNERABILITY ASSESSMENT FOR RESOURCE MANAGEMENT OF A NATURAL PROTECTED AREA
}

\author{
MARIO DANIEL VERDUGO, OSCAR ARIZPE \& ARTURO GONZALEZ-BAHEZA \\ Autonomus University of Baja California Sur, Mexico
}

\begin{abstract}
The present study analyzes the vulnerability assessment as a tool and reference for a sustainable managing of the Natural Protected Area (NPA) San Jose del Cabo Estuary Mexico (ESJC). ESJC is a coastal oasis of fresh water located close to the Gulf of California mouth, and it is an important refuge for migratory birds and endemic species that inhabit the estuary. ESJC has been threatened by the rapid urbanization and tourist development in Los Cabos, which created negative effects such as land changes, sewage discharges and invasive species, affecting largely the quality of the estuary. In this context the main purpose of the study was to evaluate the vulnerability of every micro region of ESJC in order to propose management strategies of the NPA. We made a characterization and regionalization of ESJC. We propose an index (VI) based on indicators to represent the vulnerability, as well as the natural and socio-ecological pressures affecting the refuge. The VI was shaped adding fragility index (FI) and pressure index (PI). The FI and PI were created from the indicators that were normalized to dimensionless quantities ranging from 0 to 1 . In result, the indexes infer a high vulnerability of the lagoon and the upstream area with natural vegetation: The FI shows the frailty due to runoffs, sediments, natural vegetation, endemic species and exposed population; the PI represents high values of pressure from tourism development, demography, runoff from floods, and the agricultural and urban activities. The integrated vulnerability evaluation from biophysical and socioeconomic aspects for a protected area allows an establishment of a management proposal strategy for sustainability of the ESJC.

Keywords: vulnerability assessment, sustainability, pressure, fragility, natural protected area.
\end{abstract}

\section{INTRODUCTION}

Vulnerability is a daily use word that refers to the property of a system to be arm by potential adverse effects, evaluate the vulnerability of a system suppose future arm so vulnerability is a predictive concept [1], [2]. The present vulnerability of a certain region is related with is environmental status and the pressures exerted on it by socio-economic factors [3], hence a vulnerability analysis must integrate environmental, social, economic and institution aspects to achieve sustainability. A region is more sustainable to the extent that is less vulnerable. In this regard is important to implement actions to enhanced sustainability of the Natural Protected Areas (NPA).

The assessment and monitoring of vulnerability in NPA should be able to influence the environmental policy and guiding decision makers to provide elements for the sustainability of the NPA [3]. Thus, researchers and decision makers are willing to act in the most vulnerable sites of the NPA. NPA are created to conserve areas where the native environment has not been highly modified or areas that requires to be preserved or restored and provide benefits and services to the neighboring communities [4]. The vulnerability assessment in the San Jose del Cabo Estuary (ESJC) turns into a very important concern because provides a description of the pressures and fragilities that are acting on it, either by anthropic or natural factors helping to increase the sustainability of the reserve [5], [6].

\section{METHOD}

The ESJC is a coastal oasis of fresh water located close to the Gulf of California mouth, and it is an important refuge for migratory birds and endemic species that inhabit the estuary. The 
ESJC is located in the southernmost portion of the Baja California Sur state and is surrounded by San Jose del Cabo population at west and other minor communities to northeast, in Los Cabos municipality (Fig. 1). The ESJC distinguish for its environmental and socio-economic importance, and this ecosystem has great relevance to the region, both for the water and biological perspective [7]. The region has the highest population grow rate of the country and also has become one of the fastest growing tourist destinations in Mexico, and it relies on high level infrastructure to attend the visitors, which created negative effects such as land changes, sewage discharges and invasive species threaten the stability of the estuary [7], [8].

Define an influence area for an NPA allows establishing a management scheme besides the protected area in order that the NPA not be isolated, the importance of the influence area is that possess a close relation with the NPA where the communities are settled and furthermore has the same natural process that the NPA [9]. We determine the influence area for the ESCJ with the framework proposed by Dominguez [9]; through micro criteria of terrain levels from Digital Elevation Model (DEM) and population limits resulting in the study area containing the ESJC.

ESJC was characterized based on topography, geology, watersheds, vegetation, land use, edaphology. Four base maps (watershed, geology, edaphology and land use) were developed and corrected with field observation and high-resolution satellite images to have a finest scale. All the compiled information where integrated in a Geological Information System (GIS), in Universal Transverse Mercator projection, WGS84 datum and units in meter. The intersection of the four layers was realized to obtain different homogeneous environmental units (EnvU) in terms of their attributes.

Conceptual model of vulnerability proposed for the ESJC was derived from the pressurestate-response model from OECD [10] and modified where a system state or fragility is modified due to the application of a force of pressure. A vulnerability index (VI) was proposed based on indicators to represent the vulnerability of the ESJC. The VI was created adding the pressure index (PI) that integrated both external and internal factors and the fragility index (FI) that integrated physical, environmental and socioeconomic factors. Normalization was needed to obtain values with dimensionless quantities ranging from 0 to 1. Values from indices where compared between them in each EnvU [11].

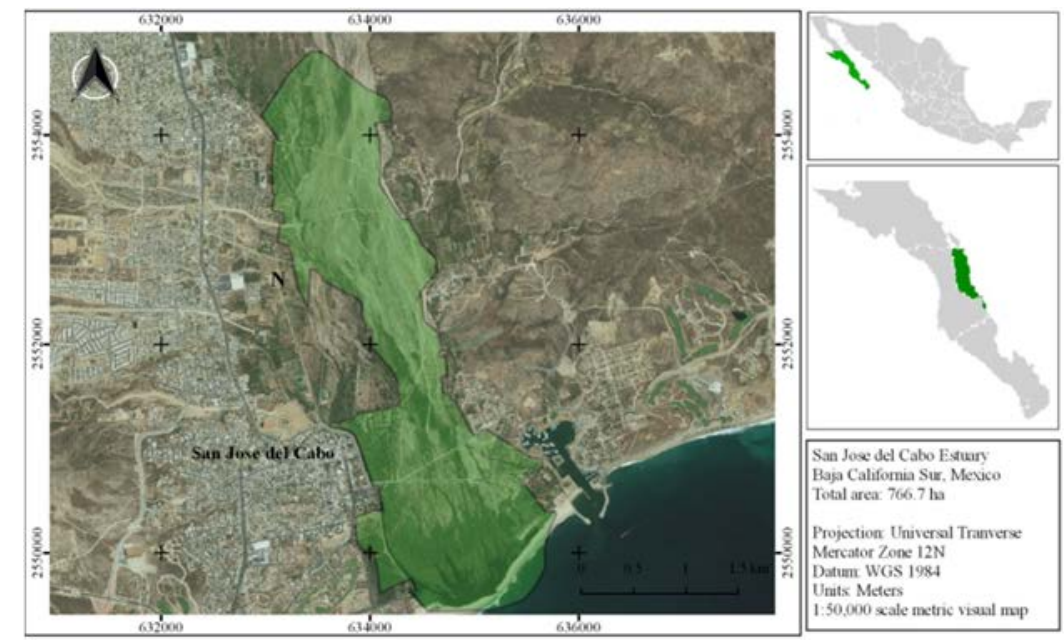

Figure 1: Localization map and resent area of the San Jose Del Cabo Estuary. 


\section{RESULTS AND DISCUSSION}

The study area was 2,476.78 ha, 766.7 ha from the ESJC plus the influence area $(1,710.08$ ha), we obtained 30 EnvU derived from the regionalization. 5 EnvU were in contact with coastline representing $14 \%$ of the total area, the ESJC area represented $31 \%$ within 11 EnvU. The VI was implemented in the 30 EnvU considering three components: 1) a fixed part defined by the VI containing the FI and the PI. The FI was formed with five second order sub-indices, naturalness (In), richness (Ir), susceptible population (Isp), hydrologic (Ih) and geophysics (Igf); the PI with four second order sub-indices, demographic (Ide), environmental impact activities (Iia), potential flooding (Ipf), tourism (It). 2) adaptable part of the model with 34 indicators forming the second order sub-inidces. 3) and the mathematical component to standardize and integrating the indices by simple addition, with weighted algorithms by expert consulting work. Hence the FI was obtained by the sum of In+Ir+Isp+Ih+Igf; and the PI was obtained by the sum of Ide+Iia+Ipf+If.

The results of FI map (Fig. 2(a)) showed high and very high fragile EnvU located in center part of the area in the alluvial plain of arroyo San Jose and the east part in arroyo Los Alamos. The two EnvU of the Estuary were the most fragile ( $\mathrm{FI}=0.87 \& 0.93$ ) because its high ratio of naturalness, vegetation and bird richness, and for being in the alluvial plain of arroyo San Jose that the geophysics $(\mathrm{Igf}=0.62 \& 0.77)$ and hydrologic $(\mathrm{Ih}=1 \& 0.61)$ indices were high and very high. The same occur with the bigger EnvU at north of the area presenting the geophysics index higher value (Igf=1). The PI (Fig. 2(b)) showed the higher values of pressure in the southeast part of the area and in general the PI was medium, low and very low for most of the study area (87\%) including all the ESJC. These results must take it carefully because the high values of PI are from San Jose del Cabo urban area and from tourism infrastructure, therefore this increase the pressure to the ESJC in consequence of the use of the estuary.

Table 1: Sub-Index and Indicators used to estimate Fragility Index (FI).

\begin{tabular}{|c|c|c|}
\hline SUB-INDEX & \multicolumn{2}{|c|}{ INDICATORS } \\
\hline \multirow{3}{*}{$\begin{array}{l}\text { Naturalness } \\
\text { Index } \\
\text { (In) } \\
\end{array}$} & \multicolumn{2}{|c|}{ Natural land cover in 2013 , based on official map data } \\
\hline & \multicolumn{2}{|c|}{ Natural land cover ratio in each EnvU } \\
\hline & \multicolumn{2}{|c|}{ Protected area indicator, presence/absence of AICA or Ramsar site in each EnvU } \\
\hline \multirow{4}{*}{$\begin{array}{l}\text { Richness Index } \\
\text { (Ir) }\end{array}$} & \multicolumn{2}{|c|}{ Flora species richness in each EnvU, based on official vegetation map } \\
\hline & \multicolumn{2}{|c|}{$\begin{array}{l}\text { Flora species with protection status in each EnvU, according to the NOM-059-SEMARNAT- } \\
2010\end{array}$} \\
\hline & \multicolumn{2}{|c|}{ Bird species richness reported for the AICA in each EnvU } \\
\hline & \multicolumn{2}{|c|}{ Forest representation, number of EnvU by type of land use and vegetation } \\
\hline \multirow{4}{*}{$\begin{array}{l}\text { Susceptible } \\
\text { population } \\
\text { index (Isp) }\end{array}$} & Illiterate population over age 15 in each EnvU & Illiterate population density in each EnvU \\
\hline & $\begin{array}{l}\text { Older population indicator (over } 65 \text { years old) } \\
\text { in each EnvU }\end{array}$ & $\begin{array}{l}\text { Older population density (over } 65 \text { years } \\
\text { old) in each EnvU }\end{array}$ \\
\hline & $\begin{array}{l}\text { Children population indicator (under two } \\
\text { years old) in each EnvU }\end{array}$ & $\begin{array}{l}\text { Children population density (under the two } \\
\text { years old) in each EnvU }\end{array}$ \\
\hline & Total number of dwellings in each EnvU & House density in each EnvU \\
\hline \multirow{3}{*}{$\begin{array}{l}\text { Hydrologic } \\
\text { Index (Ih) }\end{array}$} & \multicolumn{2}{|c|}{ Watershed representativeness, number of EnvU by watershed } \\
\hline & \multicolumn{2}{|c|}{ Stream density, number of streams/EnvU } \\
\hline & \multicolumn{2}{|c|}{$\begin{array}{l}\text { Potential flood affectation, number of run off }+ \text { maximum Strahler order of stream segments } \\
+ \text { mean slope (degrees) in each EnvU }\end{array}$} \\
\hline \multirow{5}{*}{$\begin{array}{l}\text { Geophysics } \\
\text { Index (Igf) }\end{array}$} & \multicolumn{2}{|c|}{ Weighted landform indicator, more weight for lowland areas } \\
\hline & \multicolumn{2}{|c|}{ Weighted watershed slope indicator, greater weight to low slopes } \\
\hline & \multicolumn{2}{|c|}{ Landform representativeness, number of EnvU by landform type } \\
\hline & \multicolumn{2}{|c|}{ Stream energy indicator, basin hypotenuse + average slope (degrees) of each EnvU } \\
\hline & \multicolumn{2}{|c|}{ Land cover ratio with slope $\leq 2^{\circ}$ for each EnvU } \\
\hline
\end{tabular}


Table 2: Sub-Index and Indicators used to estimate Pressure Index (PI).

\begin{tabular}{|l|l|}
\hline SUB-INDEX & INDICATORS \\
\hline \multirow{3}{*}{$\begin{array}{l}\text { Demographic Index } \\
\text { Ide }\end{array}$} & Population density indicator, total EnvU people/ EnvU area, from 2010 census data \\
\cline { 2 - 2 } & $\begin{array}{l}\text { Demographic change indicator, geometric population growth rate for 2005 - 2010 } \\
\text { periods }\end{array}$ \\
\cline { 2 - 2 } & Economically active population in each EnvU from 2010 census data \\
\hline $\begin{array}{l}\text { Environmental impact } \\
\text { activities Index (Iia) }\end{array}$ & Ratio of the EnvU with agricultural activity, from land use map \\
\cline { 2 - 2 } $\begin{array}{l}\text { Potential flooding } \\
\text { Index (Ipf) }\end{array}$ & $\begin{array}{l}\text { Patio of the EnvU cover with urban area, from land use map } \\
\text { 100m buffer for 3 and 4, 50m buffer for 1 and 2 }\end{array}$ \\
\cline { 2 - 2 } & Population affected by runoff in each EnvU \\
\cline { 2 - 2 } & Potential runoff density, potential for runoff/total area in each EnvU \\
\hline Tourism Index (It) & Hotel activity indicator, number of hotel rooms for each EnvU \\
\cline { 2 - 2 } & Land cover ratio with tourism infrastructure in each EnvU, hotels and golf courses \\
\cline { 2 - 2 } & Attractive naturalness indicator, presence/absence of natural attractive of the ESJC \\
\hline
\end{tabular}

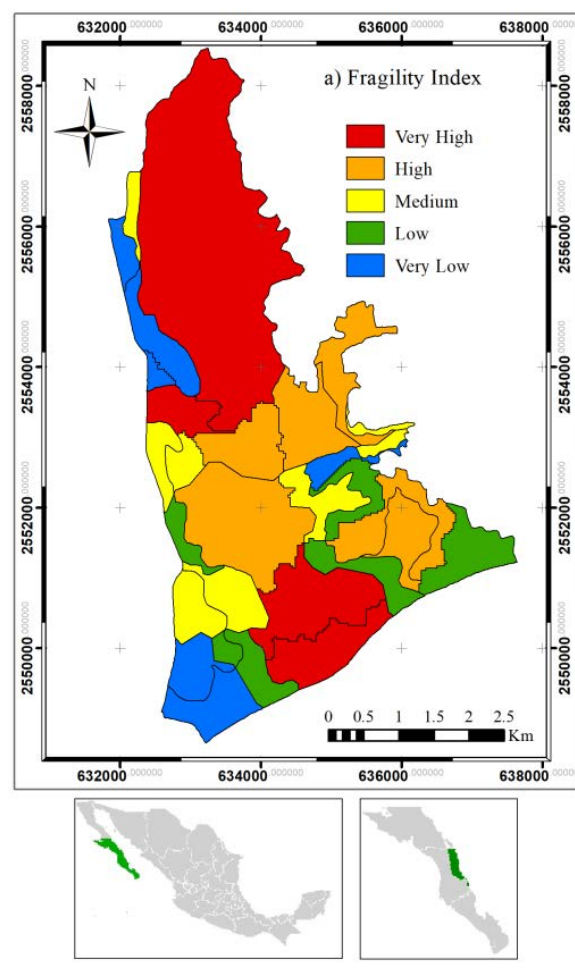

(a)

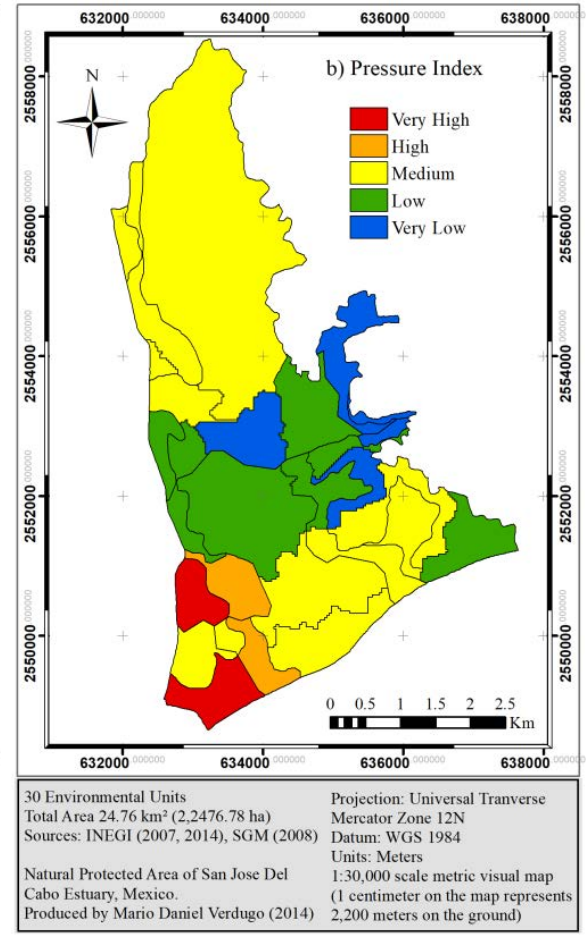

(b)

Figure 2: Index Maps. (a) FI map with fragile EnvU in north and south region; (b) PI map showing the pressure on the southwest area.

The VI results from the mathematical addition of the natural fragility and the pressures that are affecting on the area. The final map (Fig. 3) showed a regional vulnerability at south and north parts of the study area. The high and very high vulnerability represents $53 \%$ of the total area (1,302.55 ha). The $31.7 \%$ (243.26 ha) of the ESJC area presents very high 
vulnerability. The north area include two EnvU with the higher vulnerability values $(\mathrm{VI}=0.88$ $\&$ 0.94), this is because the high levels of geophysics (Igf), hydrologic (Ih) and potential flooding (Ipf) indices, this results reproduces the natural features of the region being an alluvial plain and having the primary stream of the San Jose del Cabo basin, furthermore with the risk of flooding caused by storm rains. The main channel of water from the San Jose del Cabo basin feeds the estuary, also the San Jose del Cabo basin is the main source of supply of water for the region. The south region of high vulnerability contain the estuary of the NPA, this is mainly for is naturalness as we mentioned above. The importance of the estuary is well documented for the researchers and local authorities (arizpeWIT), so this area is under a lot of pressure for the anthropic activities.

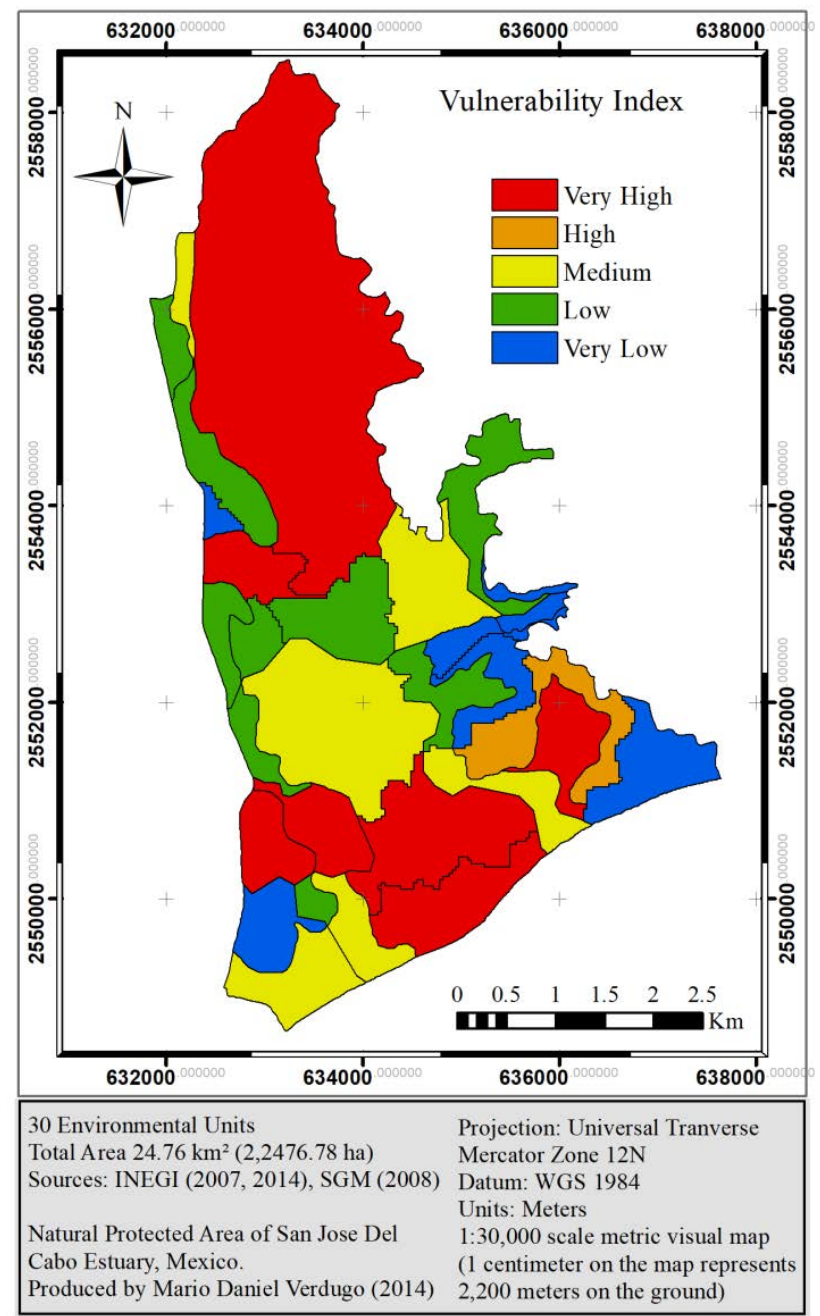

Figure 3: Vulnerability Index of the ESJC and its area of influence, most vulnerable areas are in north and south regions. 
The proposed model and indicators make evident the characteristics of the region; the VI is well represented by geographic-landscape features with specifics threats and the social indicators are easily accessible in the government database. It is suggested to use statistical methods to adjusting the model or apply a sensitive analysis for the indicators to strengthen the results, however the present study represent the vulnerability of the ESJC. The study gives a representation of the reality and easily communicates results to users, the fact that the vulnerability can be identified in space makes easier to act in this region with policies that enhance sustainability.

There are works that evaluate vulnerability in NPA with management purpose [12]-[14] and demonstrate that the vulnerability analysis can be an important step to turn into public policies and give the decision makers the tools for management the natural resources of the NPA. The determination of natural fragility, the pressures that are influencing the area and the final evaluation of vulnerability, allow knowing the current state of the system, becoming an important tool for the decision makers for the development of a program management.

[1] De Bruijn, K. M., Green, C., Johnson, C. \& McFadden, L., Evolving concepts in flood risk management: searching for a common language. In Flood risk management in Europe, Springer, Dordrecht, pp. 61-75, 2007.

[2] Wolf, S., Vulnerability and risk: comparing assessment approaches. Natural Hazards, 61(3), 1099-1113, 2012.

[3] González-Baheza, A. \& Arizpe, O., Vulnerability assessment as a support for a sustainable coastal city: a case study of La Paz, Mexico. Coastal Cities and their Sustainable Future, 148, p. 25, 2015.

[4] Secretaria del Medio Ambiente y Recursos Naturales, Programa Nacional de Áreas Naturales Protegidas 2014-2018, SEMARNAT, México, p. 155, 2014.

[5] Arizpe, O.\& Gonzalez-Baheza, A., Vulnerabilidad y su importancia en las escalas de evaluación, prospectiva y ordenamiento ecológico. International Congress of Territorial and Ecological Ordinance, 2013.

[6] Liu, X., Wang, Y., Peng, J., Braimoh, A.K. \& Yin, H., Assessing vulnerability to drought based on exposure, sensitivity and adaptive capacity: a case study in middle Inner Mongolia of China. Chinese Geographical Science, 23(1), pp. 13-25, 2013.

[7] Arizpe, O., Juarez, J., Cruz, P. \& Torres, A., Evolution of a coastal oasis in a high population growth rate municipality: Los Cabos, Mexico. International Journal of Sustainable Development and Planning, 13(4), pp. 605-613, 2018.

[8] Lauterio, C. \& Arizpe, J.U.O., Proposing strategies for a sustainable tourism: a case study of El Sargento and La Ventana, BCS, Mexico. Sustainable tourism V, 2012.

[9] Domínguez, E., Conectividad biológica y social: zonas de influencia de las Áreas Naturales Protegidas, CONABIO, México. p. 134, 2009.

[10] Organization for Economic Co-Operation and Development (OECD), OECD Core Set of Indicators for Environmental Performance Reviews, Environmental Monograph \#83, Paris, http://www.fao.

[11] Nijkamp, P., Rietveld, P. \& Voogd, H., Multicriteria Evaluation in Physical Planning, Amsterdam: North-Holland, pp. 65-100, 1990.

[12] Nandy, S., Singh, C., Das, K., Kingma, N. \& Kushwaha, S., Environmental vulnerability assessment of eco-development zone of Great Himalayan National Park, Himachal Pradesh, India. Ecological Indicators, 57, pp. 182-195, 2015. 
[13] Qiu, B., Li, H., Zhou, M. \& Zhang, L., Vulnerability of ecosystem services provisioning to urbanization: A case of China. Ecological Indicators, 57, pp. 505$513,2015$.

[14] Whitelaw, P., King, B. \& Tolkac, D., Protected areas, conservation and tourism financing the sustainable dream. Journal of Sustainable Tourism, 22(4), pp. 584-603, 2014. 